\title{
Customizing Crowdfunding Approaches to Replace "Biased" Funding
}

\author{
Ophir Flomenbom \\ Flomenbom-BPS Ltd \\ 19 Louis Marshal Tel Aviv 62668, Israel \\ ophir1974@flomenbom.net \\ Jelena Mazaj \\ CESIE, Italy Via Roma 94, 90133 Palermo, Italy \\ jelena.mazaj@cesie.org \\ Received 24 February 2017 \\ Revised 24 May 2017 \\ Published 19 July 2017
}

\begin{abstract}
The purpose of this paper is to deal with crowdfunding approaches' strength to influence the society, in particular, reforming the funding power structure in the society, to restructure the society wealth distribution, and to increase the flow of opportunities in the nation. The approaches that can do that include local crowdfunding from within businesses, crowd funds' entities that are combined with unbiased management, and those combined with unbiased bank's support. Local crowdfunding from within businesses is indeed a unique tool for financial stability at the neighborhood level, yet also in the nation's level upon generalizations, where these can shift socio-economic-power to the citizens. In generalizing crowd funds' entities, these are of value to fight biases in case combined with unbiased management; "unbiased crowdfunding" might prove simpler to create and maintain than the alternatives. Some of the example of works that we performed with local businesses are presented in this paper.
\end{abstract}

Keywords: Crowdfunding; financial stability; economic crisis; fairness; society.

PACS: 89.65.-s, 89.65.Gh, 89.65.-s

\section{Introduction}

In this commentary, we deal with crowdfunding approaches' influence on the society. The funding to activities from the group of many citizens (that in most cases organize just to achieve the goal of the particular funding $)^{1-19}$ rather than e.g., banks, is defined as crowdfunding. This can fund almost anything, ranging from the developments of musical albums, to constructing buildings, developing cars and

This is an Open Access article published by World Scientific Publishing Company. It is distributed under the terms of the Creative Commons Attribution 4.0 (CC-BY) License. Further distribution of this work is permitted, provided the original work is properly cited. 
performing research, etc., where the organizing entities can also vary. Here, we ask whether and how crowdfunding approaches can shift funding's and financial strength to the citizens, increase the flow of opportunities, yet can also stabilize the society, and restructure the wealth density in the nation. Among the conclusions, we emphasize here that local crowdfunding from within small and intermediate businesses can make a difference locally, stabilizing these businesses that create such funds. In generalizations, crowdfunding is a powerful approach to influence societies in case combined with pro-99\%-managed-banks, such that these bank-like crowd funds' entities are operating with unbiased management, where such entities are simpler to create than to change the current banking system.

The first few sections in this work are about the traditional funding alternatives, identifying the problems that crowdfunding can solve. Then, the third and fourth heading treat crowdfunding's, presenting the description, the strength, and problems and solutions of crowdfunding, yet also deal with the possible influence and the ability to create "unbiased" funding options, better opportunities and wealth densities, with crowdfunding unique approaches, where various examples of work performed by us with local businesses are presented.

\section{Current Funding Alternatives}

In funding, we characterize the system based on the identification of the lender, the borrower, the goal, and the benefits. There are many funding forms' sorts and types that complement the public sector activities that are financed from the tax payer money ${ }^{14-17}$; e.g., funding for individuals, small and intermediate businesses, not for profit organizations, innovations, start-ups (early stage companies), big organizations, etc., where funding can arrive from private entities, banks or government's entities. $^{3,7,20}$ The goals vary from making basic living, developing innovations, doing research, dealing with charity, etc. The benefits and rewards to the funders are either due to interest on the money (traditional finance), fortune, stocks and shares, or receiving products, or winning prestige, among the major goals of funders in crowdfunding.

The traditional funding is described by three $\operatorname{circles}^{9-11}$ : organizations with the money (lenders), parties that need the money (borrowers) and the intermediate (those that deliver the money from the lender to the borrower). These sides are presented in Table 1, and Fig. 1.

The organizations with the money include:

(a) Banks and credit cards companies. Although a bank/credit company is in principle an entity that just delivers money from "savers" to "borrowers", the "intermediate" in the banks lend money which they do not have, they "create" money from the "thin air", ${ }^{21,22}$ these are traditionally in the category "entity with the money". The issue on how much the banks lend money and equityowned is known as the bank's capital requirement or capital adequacy ratio. ${ }^{23}$ 


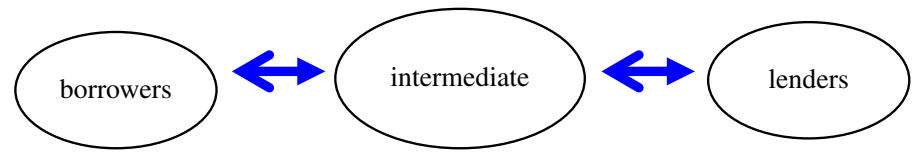

Fig. 1. The most basic illustration of the funding structure, where Table 1 complements the figure's explanation and explains who the various parties are in the figure.

This is discussed just in an economic crisis era. ${ }^{21,24}$ Crowdfunding might stabilize the economy (minimizing harsh situations and crises that are due to banks' failures). In this commentary yet, we focus our attention on to whom the banks lend and in what conditions rather than claim that the capital adequacy ratio of unity (what is termed the "Chicago plan", e.g., Ref. 24) is the indication of fairness and social stability (fairness should create smooth wealth densities, and that's the way to decide about the effect of each socio-economic plan).

(b) Traditional funding from the public funding organizations, e.g., among various examples, the governmental offices that fund private activities include those responsible of small businesses development, agriculture stability, housing, and other particular examples, e.g., the "chief scientist department" that funding the incubators that should support innovations.

(c) Private equality funds, and investment banks with money (perhaps those in the banks). These are entities with money that lend the money to special projects in most cases.

(d) Endorsements, funds of charity, etc. These are organizations, funds and also individuals that support charity entities and people in need.

(e) Other entities, ranging from individuals, family, the community, to the "gray market". In particular, the problematic "gray market" (problematic since the conditions on the money cause people to collapse financially) is about (in many nations) $15 \%$ of the lending capacity to private people and entities. ${ }^{\text {a }}$

Crowdfunding can compete with all. Each of the entities above has the indeterminate entity that they work with. In banks and credit card companies, these are just the clerks that work for these, where other intermediates include the traditional investment banks (without money) (e.g., that take rewards based on the success), private people, etc. The intermediates are crowdfunding's software replacements, where the crowd that has the money replaces the entity with the money in the list above, see also Table 1 .

The "biased" funding system There is a lot to say about the problems with the banking system, ${ }^{22,26}$ from stability issues, to the role in crony economics. We deal in this commentary's section with the biases in the current funding entities, in banks in particular as the other lending organizations to the masses duplicate the banks' behavior. When talking about biases from the bank, we emphasize here just the issue

a The grey market appear in various parts of the economy, in parallel imports, in finance, and in other branches of the economy, where the financial gray market size is about $10-15 \%$ in most nations. 
Table 1. The parties of the funding world.

\begin{tabular}{lcc}
\hline Borrowers & \multicolumn{1}{c}{ Intermediate } & Lenders \\
\hline $\begin{array}{l}\text { Citizens, businesses, } \\
\text { companies, etc. }\end{array}$ & $\begin{array}{c}\text { Clerks, bankers, Credit card } \\
\text { clerks. }\end{array}$ & $\begin{array}{c}\text { The bank/credit card company, the } \\
\text { central bank, the government- } \\
\text { banking system that "protect" the } \\
\text { bank leverage. }\end{array}$ \\
$\begin{array}{l}\text { Entrepreneurs, start ups, } \\
\text { etc. }\end{array}$ & $\begin{array}{c}\text { Investment banks, government } \\
\text { funds. }\end{array}$ & $\begin{array}{c}\text { Businessmen and banks, government } \\
\text { tax payers' money. }\end{array}$ \\
$\begin{array}{l}\text { People in trouble. } \\
\text { People in trouble. }\end{array}$ & to help people in trouble. & $\begin{array}{c}\text { Public and government. } \\
\text { Gray market "soldiers". }\end{array}$ \\
\hline
\end{tabular}

that banks lend money to the masses with higher interest rates than to the top, therefore influence on, who has the edge in society, who will collapse, who will barely make it and who will make the fortune. Just the conditions on which the money was borrowed (can) determine all these. These issues appear also in the comparison of the top $20 \%$ and the top $1 \%$. The biased funding creates (a lot from) the gap in the wealth density top percentile and the rest ${ }^{21}$ and the accumulation of money at the top $1 \%$. The biased funding practically creates the top $1 \%$ and determines their strength. We emphasize that when banks collapse, the government "bailout" the banks rather than the citizens, ${ }^{21,27}$ further showing the distorted power structure in the society.

We can ask why the free economy did not create competitive and stable alternatives. The answer is that the politico-financial elite fight these approaches. Crowdfunding might form the platform for such possibilities, in case the public participates. From the viewpoint of fairness, crowdfunding is perhaps the simplest organization to replace the "biased" funding and to create fairness in funding, in case combined with unbiased management.

\section{Description of Crowdfunding}

The basic types of crowdfunding include, (a) funds that are based on financial rewards, where the lenders receive during the funding period, the fund plus the interest rate, (b) funds that are based on rewards in the form of percentages from the activities' flow of money, where the lenders purchase in practice part from the entity that raised the fund, (c) funds where the lenders will receive a copy of what is created, e.g., music CD, a book, a pen, etc., (d) charity crowdfunding, where the lenders receive political power and other benefits.

Summarizing, a crowdfunding is the financing method that links different market players by a possibility to invest money in brave new activities to those that have problems with attracting finance using traditional mechanisms. It is beneficial for backers, and borrowers, yet also for the economy in total, in creating jobs, advances innovations and the wellbeing of the society. 
Crowdfunding is as old as the basic cooperation of people in their activities in the community that are taking place in many forms and places. ${ }^{2-4}$ It is everywhere when people organize to fund activities, either with their labor force as the simplest example, or with raising the budget to hire others as the more sophisticated approach. The NY statue of liberty funding came from a crowd of $(120,000)$ people each investing various amounts of dollars. Today, most of the people view crowdfunding as just the online software through the internet, where with that people can communicate, those with the money and those that ask for the money, in particular to invent a gadget or to create art. Yet, we can see generalizations in other directions to other areas, e.g., in funding science, ${ }^{5}$ in car development, in medicine, etc. The internet allows crowdfunding borrowers to get finance by attracting relatively small contributions from a large number of individuals, ${ }^{12,30}$ yet, we claim here that crowdfunding is much more robust and can appear everywhere (going much beyond the Internet applications). Yet, the crowdfunding management is the issue to focus on, the matter that can decide about the direction of the fund and the fund's ability to help the citizens to fight biases in funding from the 1\%-biased-banking institutions. These are the important things that need to be focussed on rather than just the technicality.

\section{Crowdfunding: Challenges, Problems and Solutions}

Issues with crowdfunding can arise from various sources. Many are just similar to those in the other funding forms. Others are similar to technical issues as those observed in the automated trading platforms; we can talk about technical issues with the fund software, money flow, etc. There are responsibilities issues (management), stability of the projects, financial stability of the crowdfund (including the number of participants), etc. Yet, the management in the fund is the central matter that shapes the features of the fund. We can talk about biases in funding, hoaxes (failures in filtering weak projects) and whether these funding organizations will duplicate "biased" funding with biases towards inner circles (it is simple to point at all sorts of scenarios that show biases toward particular projects). Turan in ${ }^{20}$ talked about duplication of (at least of various reasons that caused) the 2008 subprime mortgage also in crowdfunding entities, also emphasizing that the management of the fund is the matter to focus on.

Unbiased crowdfunding our view is that the technical issues are solvable. ${ }^{1-19}$ Solving the issues that stem from a biased management depends on who controls the fund management and the strength of the influence of the crowd on the management, what we can define in the better case, "crowdfunding with crowd management" to create the unbiased crowdfunding. The entity can fund everything ranging from private people to businesses.

Crowdfunding can create an unbiased funding in a much simpler manner than changing the current banking system. Unbiased funding is highly in need among 
the masses, "the $99 \%$ circle", since this group experiences the biases in funding from the traditional funding structure. Crowdfunding with complementary participation of banks with "pro 99\% management" can replace the traditional biased funding and is simpler to create. The people will organize together to decide on the professional management that will execute unbiased funding schemes. Clearly, crowdfunding where the participants are those that decide on the conditions ${ }^{\mathrm{b}}$ might help solve crony economics. Crowdfunding with crowd management with support from a banking entity (bank \credit union) can replace the traditional bank.

Local crowdfunding. A fund of the crowd that is local, or with local features, might also solve problems that are due to the anonymity of participants, or stability issues. The fund can create just projects that are local, yet also combining with other unique properties. We might also suggest interactions among funds to increase financial stability, still with powerful filtering strength (e.g., borrowers can recruit from other funds just in case they have $33 \%$ from the budget from local supporters).

Yet, local crowdfunding can have other forms, perhaps the simplest form creates the fund from within the local business. In the 4th quarter of 2016, we (OF) worked with managers in local supermarkets in Tel Aviv to create such a local crowdfund. The supermarket manager has been advertising with leaflets and messages on boards in the supermarket that "customers can participate in the fund to win $20 \%$ off from all purchases, in case paying on the day where they join the fund the amount that they usually purchase with during a typical quarter". The computations showed that in case the purchases are doubled (or at least increased $\times 1.5$ ) on the amount financed with the fund, the crowdfunding is beneficial. The benefits to the supermarket's manager are in closing the debt in the bank and showing an increase in the flow of purchases. In practice, the fund made the situation that most people that participated in it purchased things that they usually buy in bigger supermarkets, making the fund very beneficial to both sides.

We can duplicate that in any business. The success of such local crowdfund from within the business depends on the manager's abilities to organize the fund's participants. We might help the businesses with (a) developing free software to upgrade the cashiers to include list of participants and their surplus in the fund, yet also with $(\mathrm{b}, \mathrm{c})$ preparing documents about "how to approach the costumers", and manage the fund. Creating such an organization that will work with businesses' managers to create local crowdfunds from within the businesses, will help to popularize local crowdfunding. We can then generalize the approaches that replace the banking system, where such a modular approach might fight physiological issues that are barriers in funding (this is also known in the banking world, where people do not switch banks due to physiological issues also when they are offered better conditions, so the same problems appear also with crowdfunding and traditional banks).

\footnotetext{
b The conditions on the money doesn't decrease the fund's stability. In Fund that doesn't bias against any group and have the goal stabilizing will be determined by the equilibrium point of the interest rate values.
} 
In this work, we introduced the ideas to create "crowdfunding with crowd management", "crowdfunding with crowd management with (pro $99 \%$ circle managed) bank's support", and the "local crowdfunding from within the business" to form the funding alternatives to the masses in the most stable and simple way. These approaches can balance the biases in funding from current banks. These approaches are based on our research and work at the street level, and our scientific research on fairness in nations, ${ }^{21,27-29,32}$ showing that the biases in the banking system are the major reasons to unjust biases in wealth and opportunities in nations. As the forces in the market will try to block such approaches, all of these approaches should have entities that advance them, and since the banking system and the political system are biased, such entities should march from scientific groups and socio-economic organizations, and the citizens.

What are the amounts the citizens can allocate every month from their wages to local crowdfunding from within local businesses? and what is the effect on the small and intermediate businesses? We think that allocating $20 \%$ from the monthly income to participate in such local crowdfunds is possible and reasonable, ${ }^{\mathrm{c}}$ yet the effect to the businesses is huge, such that it can form the difference from collapse to stability in many small and intermediate businesses.

How to create funds that the citizens can utilize for their needs, e.g., in mortgages? This fund is possible in case the fund can work with a bank that has pro $99 \%$ management, to complement the fund, and to increase the fund strength. ${ }^{\mathrm{d}}$ We think that with the successes of the local crowdfunding form within businesses, we can generalize the crowdfunding approach that can replace the biased banking system, possible with the support of a general organization composed of scientific groups and companies and socio-economic organizations.

How much local crowdfunding from business can save the lenders and how much the generalizations can save, and how these can restructure the wealth density? The local crowdfunding from within businesses can save $20 \%$ on the amounts purchased there. The generalizations of crowdfund with crowd management with complementary (pro 99\% managed) bank's support to replace current banks can save $33 \%$ and more on all expenses, to the borrowers. The resulting effect on the gaps in the wealth density $^{\mathrm{e}}$ is huge, making the density much smoother. Practically, the top $1 \%$ unjust wealth is redistributed to the entire nation, and this is the most (more than 50\%) of the top $1 \%$ wealth. Table 2 presents these matters.

Meantime, even if the crowdfunding provides people and business the opportunity to receive money that they do not have easy access to from traditional financing sources, and save time, there is still legal work to do and approval procedures to

\footnotetext{
${ }^{\mathrm{c}}$ Local crowdfunding creates the situation where people go more to a particular place. Since people might want diversification, we compute here $20 \%$ from wages as a reasonable amount to allocate to such initiatives.

${ }^{\mathrm{d}}$ For example, the pro $99 \%$ managed bank will participate in funding just in case where the borrowers recruited $33 \%$ from local lenders in the crowdfund.

e In the per nation wealth density, there are three gaps typically, at the $90 \%, 1 \%$ and $0.1 \%$.
} 
Table 2. The three unique crowdfunding approaches to replace biased funding.

\begin{tabular}{|c|c|c|c|}
\hline & $\begin{array}{l}\text { Crowdfund from within } \\
\text { the businesses }\end{array}$ & $\begin{array}{l}\text { Crowdfund with crowd } \\
\text { management }\end{array}$ & $\begin{array}{l}\text { Crowdfund with support } \\
\text { from bank/credit union }\end{array}$ \\
\hline Amounts & $5000 \$$ & $50000 \$$ & Any amount. \\
\hline $\begin{array}{l}\text { Benefits to those that } \\
\text { invest }\end{array}$ & $\begin{array}{l}20 \% \text { discount on the } \\
\text { amounts, communi- } \\
\text { ty strengthening. }\end{array}$ & $\begin{array}{l}\text { Discount and interest* } \\
\text { shares. }\end{array}$ & Interest*, shares. \\
\hline $\begin{array}{l}\text { Benefits to those that } \\
\text { ask the money }\end{array}$ & $\begin{array}{l}\text { Fund to develop the } \\
\text { business and in- } \\
\text { creased flow of cus- } \\
\text { tomers and } \\
\text { purchases. }\end{array}$ & $\begin{array}{l}\text { Fund to create and } \\
\text { develop, fund to any } \\
\text { activity. }\end{array}$ & $\begin{array}{l}\text { Fund to create and } \\
\text { develop, fund to any } \\
\text { activity. }\end{array}$ \\
\hline The projects & $\begin{array}{l}\text { Any business can create } \\
\text { such a fund from the } \\
\text { business. }\end{array}$ & $\begin{array}{l}\text { Business and private } \\
\text { people. }\end{array}$ & $\begin{array}{l}\text { Business and private } \\
\text { people. }\end{array}$ \\
\hline Problems to the lenders & Business bankrupt. & $\begin{array}{c}\text { Business bankrupt and } \\
\text { other failures. }\end{array}$ & $\begin{array}{c}\text { Business bankrupt and } \\
\text { other failures. }\end{array}$ \\
\hline Solutions & $\begin{array}{l}\text { Invest just in stable } \\
\text { places. }\end{array}$ & $\begin{array}{l}\text { Filtering through the } \\
\text { fund. }\end{array}$ & $\begin{array}{l}\text { Filtering through the } \\
\text { fund and the bank. }\end{array}$ \\
\hline
\end{tabular}

Note: *The interest rates are better than the bank's rate (e.g., $4 \%$ per year) to the borrowers, and better than what the banks suggest in the interest on savings (e.g., $1.6 \%$ per year) to lenders.

Table 3. View of various countries' actions to deal with crowdfunding. ${ }^{31}$

\begin{tabular}{lccccccc}
\hline Actions/Countries & USA & UK & Canada & Germany & France & Australia & Italy \\
\hline $\begin{array}{l}\text { Create a legal framework for } \\
\quad \text { crowdfunding }\end{array}$ & $\mathrm{V}$ & $\mathrm{V}$ & $\mathrm{V}$ & $\mathrm{V}$ & $\mathrm{V}$ & $\mathrm{V}$ & $\mathrm{V}$ \\
$\begin{array}{c}\text { Explain how crowdfunding works } \\
\quad \text { to web entrepreneurs }\end{array}$ & $\mathrm{V}$ & $\mathrm{V}$ & $\mathrm{V}$ & $\mathrm{V}$ & $\mathrm{V}$ & $\mathrm{V}$ & $\mathrm{V}$ \\
$\begin{array}{c}\text { Support a quality label for crowd- } \\
\quad \text { funding platforms }\end{array}$ & $\mathrm{V}$ & $\mathrm{V}$ & & & $\mathrm{V}$ & & \\
$\begin{array}{c}\text { Explain how crowdfunding works } \\
\quad \text { to potential investors }\end{array}$ & $\mathrm{V}$ & & & & & & \\
$\begin{array}{l}\text { Promote successful crowdfunding } \\
\quad \text { cases }\end{array}$ & $\mathrm{V}$ & $\mathrm{V}$ & $\mathrm{V}$ & $\mathrm{V}$ & $\mathrm{V}$ & $\mathrm{V}$ & $\mathrm{V}$ \\
$\begin{array}{c}\text { Create an overview of good } \\
\text { crowdfunding platforms for web }\end{array}$ & & $\mathrm{V}$ & $\mathrm{V}$ & $\mathrm{V}$ & $\mathrm{V}$ & & \\
$\quad$ entrepreneurs & & & & & & \\
\hline
\end{tabular}

develop, where the legal situation in countries differs. Developing various standard procedures could help in advancing such activities between citizens and stimulate local changes. ${ }^{31}$ Different efforts are made by countries to approach crowdfunding and make it more attractive for use in private and public sectors (Table 3), yet we also emphasize that there are examples that show that the political-financial elite interfere with crowdfunding efforts due to "hidden interests" and "control issues" and the public should organize to influence and fight these interferences. 
To conclude, we think that crowdfunding approaches can form the way to fight unjust biases from the biased banking system. The three approaches that we focused on here include, (1) local crowdfunding from within businesses, possible with simple organization from within the small businesses, (2) crowdfunds with crowd management, and (3) crowdfunds with crowd management with complementary (pro-99\%managed) bank's support. Supervision on, and support to these can come from socioeconomic organizations, scientific entities, etc., yet also from the citizens (what we defined with the term, "crowdfunding with crowd management").

\section{Acknowledgment}

We thank Gul Unal Coban for her participation in the "fairness in nations" project and also actively participating on discussion about this work.

\section{References}

1. R. E. Wheatemail, Y. Wang, J. E. Byrnes and J. Ranganathan, Trends Ecol. Evolut. 28(2) (2013) 71-72.

2. E. Mollick, The dynamics of crowdfunding: An exploratory study, J. Bus. Venturing 29 (2014) 1-16.

3. N. Siva, Crowdfunding for medical research picks up pace, The Lancet 384(\#9948) (2014) 1085-1086, doi: http://dx.doi.org/10.1016/S0140-6736(14)61661-5.

4. P. Cameron, D. W. Corne, C. E. Mason and J. Rosenfeld, Crowd funding genomics and bioinformatics, Genome Biol. 14 (2013) 134, doi: 10.1186/gb-2013-14-9-134.

5. M. MaryAnne, Everyone is a venture capitalist: The new age of crowdfunding gobble, Res. Technol. Manage. 55(4) (2012) 4-7.

6. M. D. Greenberg, B. Pardo, K. Hariharan and E. Gerber, Crowdfunding support tools: Predicting success \& failure, in Proc. CHI EA '13 CHI '13 Extended Abstracts on Human Factors in Computing Systems (2013), pp. 1815-1820, doi: 10.1145/2468356.2468682.

7. E. M. Gerber, M. Muller, R. Wash, L. C. Irani, A. Williams and E. F. Churchill, Crowdfunding: An emerging field of research, in Proc. Extended Abstracts on Human Factors in Computing Systems (CHI EA '14 CHI '14) (2014), pp. 1093-1098.

8. G. K. C. Ahlers, D. Cumming, C. Günther and D. Schweizer, Signaling in equity crowdfunding, Entrep. Theory Prac. (2015), doi: 10.1111/etap.12157.

9. L. Valanciene and S. Jegeleviciute, Valuation of crowdfunding: Benefits and drawbacks, Econ. Manage. 18(1) (2013) 38.

10. J. S. Hui, M. D. Greenberg and E. M. Gerber, Understanding the role of community in crowdfunding work, in Proc. Proc. 17th ACM Conf. Comput. Supported Cooperative Work $\mathcal{E}$ Social Comput. CSCW'14 (2014), pp. 62-74.

11. A. Moritz and J. H. Block, Crowdfunding: A literature review and research directions, in Crowdfunding in Europe (2016), pp. 25-53.

12. The EU website, https://www.crowdfunding4culture.eu/.

13. P. Belleflammea, T. Lambert and A. Schwienbacher, Crowdfunding: Tapping the right crowd, J. Bus. Venturing 29(5) (2014) 585-609.

14. L. Guan, A short literature review on reward-based crowdfunding, in 13th Int. Conf. Service Systems and Service Management (ICSSSM) (2016). 
15. G. Bruton, S. Khavul, D. Siegel and M. Wright, New financial alternatives in seeding entrepreneurship: Microfinance, crowdfunding, and peer-to-peer innovations, Entrep. Theory Pract. 39(1) (2015) 9-26.

16. R. J. Shiller, Capitalism and financial innovation, Financ. Anal. J. 69 (2013) 21.

17. L. Fleming and O. Sorenson, Financing by and for the Masses: An introduction to the special issue on crowdfunding, Calif. Manag. Rev. 58 (WINTER 2016).

18. R. Gleasure, Resistance to crowdfunding among entrepreneurs: An impression management perspective, J. Strateg. Inf. Syst. 24 (2015) 219-233.

19. P. Belleflamme, N. Omrani and M. Peitz, The economics of crowdfunding platforms, Inf. Econ. Policy 33 (2015) 11-28.

20. S. S. Turan, Crowdfunding: Friend or foe? Procedia - Soc. Behav. Sci. 195 (2015) 353-362, doi: 10.1016/j.sbspro.2015.06.334.

21. O. Flomenbom, Biophys. Rev. Lett. 10 (2015) 157.

22. D. Colander, M. Goldberg, A. Haas, K. Juselius, A. Kirman, T. Lux and B. Sloth, Cri. Rev. 21 (2009) 249.

23. J. Huber, Reflections on the Chicago plan revisited in comparison to plain sovereign money, Website for New Currency Theory and Sovereign Money (2014).

24. J. Benes and M. Kumhof, The Chicago plan revisited, IMF Working Paper (2012).

25. G. Thomas, Woodward Money and the Federal Reserve System: Myth and Reality, Congressional Research Service Library of Congress CRS Report for Congress, No. 96-672 E (1996).

26. Y. Adiguzel et al., Rep. Adv. Phys. Sci. 1 (2017).

27. A. Chatterjee, G. U. Coban and O. Flomenbom, Rep. Adv. Phys. Sci. 01 (2017) 1703001.

28. O. Flomenbom, The income Gini of fairness, Rep. Adv. Phys. Sci. 01 (2017) 1740004.

29. S. Jegelevičiūtè and L. Valančiènè, Comparative analysis of the ways ceowfunding is promoted, Procedia - Soc. Behav. Sci. 213 (2015) 268-274.

30. T. E. Brown, E. Boon and L. F. Pitt, Seeking funding in order to sell > crowdfunding as a marketing tool. Business Horizons (2016).

31. J. Mazaj, The case of civic society organization: Citizens' engagement into responsible research and innovation actions through the social media, Rep. Adv. Phys. Sci. 01 (2017) 1740010 .

32. O. Flomenbom, G. U. Coban and Y. Adigüzel, Commentary on "biophysical economics" and evolving areas, Biophys. Rev. Lett. 11 (2016) 55. 